\title{
Martin Blaszk
}

Uniwersytet Gdański

brcmart@ug.edu.pl

\section{BETWEEN DIDACTICS, THE MENTOR AND THE PUPILS: TRAINEE REFLECTIONS CONCERNING THEIR TEACHING PRACTICES}

\author{
Between didactics, the mentor and the pupils: \\ Trainee reflections concerning their teaching practices
}

Reflection in teacher development is important as it can help both experienced and novice teachers to better understand the processes they are involved in. It can also be used to aid evaluation processes. This paper presents a small scale study that involved undergraduate English philology students from Gdańsk University who were studying for the teacher specialisation. One of its purposes was to trial a strategy for feedback that could be used to mediate an already existing model of assessment for students' taught lessons, which previous to the study used only a prescribed set of assessment criteria. Another purpose was to promote a reflective turn in both the student-teacher and academic mentor (myself), which would then inform the discussions that took place after each observed lesson. In addition to this, I was interested to find out if this strategy would generate a suitable quality and quantity of information, so that it might be used for further research. Overall, the strategy proved a useful aid to reflection in relation to the students' teaching practices. As a research tool, it also generated usable data.

Keywords: teaching practices, dialogical reflection, significant others, qualitative research, pilot study

Słowa kluczowe: praktyka nauczycielska, refleksja dialogowa, ważni inni, badania jakościowe, badania pilotażowe 


\section{Introduction}

As an important part of their studies for the teaching specialisation, undergraduate students from the Institute of English and American Studies, University of Gdańsk, undertake teaching practices. These are supervised and evaluated by a school mentor, a teacher working in the school the student-teachers carry out their practices. They are also monitored by a member of faculty, an academic mentor (opiekun praktyki), who is also responsible for evaluating the practices. The evaluation undertaken by the academic mentor includes assessment of a portfolio which the students compile while they carrying out their practices. In addition to this, each semester up to 6 student-teachers are chosen at random and visited by their academic mentor. This observation and assessment of the lessons they teach acting as a supplement to the mark given for portfolios. Prior to 2012, when the latest reforms concerning practices were introduced, the form of evaluation for these lessons was based upon a prescribed set of criteria, which left little room to include the studentteachers' reflections on the lessons they had taught, or for the academic mentor to be involved in the process other than in a judgemental manner. In connection with this, as a newly appointed academic mentor, I was interested in implementing a procedure for assessment that would be more dialogical and reflective in approach, and less based on a fixed set of criteria.

\section{Theoretical background}

In second language education, evaluation of the lessons taught by novice teachers is seen as an important way to help them succeed at their task of teaching (Mann 2004), it is also believed that reflection is invaluable for the continuing professional development of teachers (Mann and Walsh 2015: 17). As part of this however, there are questions relating to who actually does the observation and evaluation, and how it is carried out (Mercado and Mann 2015: 35-36). This is especially true, as the space within which the teacher operates is highly complex, so that the application of one set of criteria or understanding of how things should be done is inadvisable (37). Additionally, there is the danger that an expert coming from outside to assess a lesson may actually harm the teacher in their development rather than help them (36). In relation to this, there have been a number of tools devised for evaluation/research based upon dialogical reflection which try to obviate such a situation (Mann and Walsh, 2015: 24-26; Wallace, 2008). Mercado and Mann (2015: 36), meanwhile, argue that the individual teacher should be kept at the centre of the evaluation process. 
In this paper, I want to present a small scale study in which a procedure for observation and feedback based upon dialogical reflection was trialled, and where the student-teacher was placed at the centre of the evaluation process. The procedure was based upon the assumption that student-teachers shape and develop their ideas about teaching in contact with a number of people, who might be considered to be significant others. This term, coined by Sullivan (1953), has a number of guises: in everyday life it is people who are close to us, usually a partner; in psychology, it is people who have an effect on our well-being; and, in sociology, people who are responsible for the development of our concept of self. In my use of the term I was interested in its sociological use, which I linked to Mead's concept of the self.

In Mead's theory of the self (1962: 158), individual selves come about as a result of social interaction, arising from relations with other people involved in activities as part of a particular (social) project. This appears appropriate in connection with student-teachers, who develop a teacher-self through contact with a number of different people during the course of their studies and practices. These include, for example, the academic staff they encounter at university who lead courses on language teaching methodology. They also include the people linked to their teaching practices in school, such as teachers and pupils. The teacher in this case, becoming a mentor for the young student-teacher. In addition to this, there is also their academic mentor, who observes a lesson taught by the student-teacher and then discusses it with her or him.

This being the case, in choosing the significant others around which to focus the discussions with the student-teachers, I decided upon: the teacher mentor; pupils - children; and, lecturers leading the methodology classes at the university, and myself as academic mentor - methodology course. I also included the trainees themselves - you - as they also brought a wealth of experience in education, both as pupils and students, but also as teachers; many of them were either teaching private lessons, or working for commercial language schools. In effect, the choice of significant others in this case was to take into account the people the student-teachers were involved with during their practices, but also the broad experience they themselves brought to their practices.

\section{The study}

The study was carried out between November 2010 and May 2013, and involved undergraduate students of the Institute of English and American Studies at the University of Gdańsk. All of the students were specialising as teachers and carried out the "old" form of teaching practices: those applicable before the reforms of 2012. At that time, I was the academic mentor for the teaching 
practices. This meant, as part of my duties, I assessed the portfolio the trainees produced in fulfilment of their teaching practices. It also meant that each semester I visited and observed a number of the students as they were teaching. However, as well as observing their lessons, I was also interested to find out how the students positioned themselves in relation to the different areas of their practices: in this case the people they had contact with throughout their duration, and who I have labelled significant others.

\subsection{Aims}

As mentioned above, one of the reasons for carrying out the study was to orientate myself within the different environments the trainees were working between. I also wanted to promote a more reflective turn in the evaluation process concerning the student-teachers' taught lessons; one which would involve both the student-teacher and the academic mentor. Additionally, I wanted to test a procedure for data collection that I hoped to use in a research project after the reforms to the teaching practices in 2012.

There were a number of reasons for wanting to know more about the wider context in which the student-teachers were operating. First of all, and practically, it allowed me to orientate myself within the different environments they were moving between, to find out more fully what they were engaged in and how they viewed themselves to be involved. This was important because being new in the institute as I was at that time, and coming fresh to this particular set of practices, I did not "know" the schools - the teachers and pupils - the students were working with, nor did I "know" the input they received on their didactics courses at the university in preparation for their practices $^{1}$. From what I could see also, the set up was similar to the situation described by Kębłowska (2006) for the practices she was involved in prior to 2001, whereby didactics input, care of the practices, and involvement of the schools were not co-ordinated.

In addition to these considerations, by getting the students to think about themselves among the people that played an important role in their practices,

\footnotetext{
${ }^{1}$ I started work in the Institute in the semester that I started working on the practices. My approach to finding out about the didactics classes was to talk to the academic staff leading them, as well as look at the available syllabuses. To a degree, there was also a common understanding of what such classes would contain, as the majority of people teaching didactics were trained using models that come from teaching English as a foreign language. However, my argument here would be that this information either read or passed on verbally, or as part of a commonly shared knowledge, is not the same as the experience of the classes themselves, and what occurs in them.
} 
I hoped to stimulate reflection that would go deeper and lead to a richer discussion than only talking about the one lesson I "parachuted in" to observe? This, I believed, would help me with my own reflections in connection with the lesson I had seen them teach; because getting the students to give as full a picture as possible of their experiences would provide me with a means to mediate my perceptions and judgement of their performance during the lesson.

Linked to the above, I also hoped that my discussions with the studentteachers would provide information from which to view them in terms of involvement in their lessons/practices that would work along with and mediate the standardised categories I was otherwise dealing with. In terms of the lessons I observed, for instance, the assessment form I was using, the Observer Evaluation Record, focused upon the performance of the student-teacher, their preparation for the lesson, and its presentation. In connection with this, meanwhile, the student-teachers were evaluated with regard to criteria such as sensitivity to learner's level and needs, clear aims of the lesson, and clarity of instructions ${ }^{3}$. There was nothing in this assessment, however, that touched upon factors which might have had an influence upon the way in which the student was actually teaching and the decisions they were making. Generally too, the fixed taxonomy of the assessment form made it difficult to go beyond a behaviouristic-instrumental view of what the students were doing in the classroom, where there was a right way to do things; in this case shared between the three possible marks given on the Observer Evaluation Record excellent, satisfactory, and improvement needed.

\section{Methodology}

In terms of methodology, the research project was qualitative and interpretive, as my aim was to open up the area of inquiry to find out what was occurring and try to understand it, not to uncover underlying social facts that are verifiable (Schwandt, 1994: 120). The project can also be described as a case study in that I was concentrating on a particular group of people involved in a particular activity (Galewska-Kustra, 2009: 231-234): BA students carrying out their

\footnotetext{
${ }^{2}$ Part of my intention here, during the course of the discussion, was to create a space with the student-teachers for broader and deeper reflection on their practices in the hope that it would have some impact not only for the remainder of their practices, but also their teaching into the future.

${ }^{3}$ The Institute also made an identical version of this evaluation record available to teacher-mentors, the Mentor Evaluation Record, which they also used to assess the students' teaching.
} 
teaching practices in state schools. In addition, it was also participatory in nature, because I was part of the phenomenon which I was researching along with the student-teachers (Heron and Reason, 1997: 284). And finally, the project was a pilot study, as I wanted to assess the inquiry technique I was using and the way it was being used (van Teijlingen and Hundley, 2001: 1). This involved the use of a guided interview embedded in the feedback sessions which took place after I had observed the lessons taught by the student-teachers. My aim overall being to see if this technique, used in this way, would yield sufficient and usable data, and would therefore prove useful in a larger scale research project I was planning for the future.

\section{Organisation of the practices in relation to the study}

In total, I observed twenty-seven students from the winter semester of 2010 to the end of the summer semester of 2013. All of these students took part in post-observation discussions, of which twenty-one were recorded. The recordings providing data for the study. The students who took part were all involved in first degree level, BA (licencjat) studies, taking the teaching specialisation offered by the Institute of English and American Studies. In addition to this, they were either $2^{\text {nd }}$ or $3^{\text {rd }}$ year students and worked in a variety of state schools at different levels: primary (szkoła podstawowa); lower secondary (gimnazjum); and upper secondary (liceum). At the time the study was carried out, the practices were organised in the following way:

$2^{\text {nd }}$ year (semester 4$)$ - primary school

$2^{\text {nd }} / 3^{\text {rd }}$ year (September and October) - lower secondary

$3^{\text {rd }}$ year (semester 5 ) - upper secondary

It is fair to say, however, that not all the students involved in the practices followed such a rigid timetable - levels and times being treated flexibly within the possibilities allowed by administrative demands, i.e. the need for students to gain feedback and a mark for each stage of their practices by a given deadline. In addition to this, there was also a further component to the practices involving cultural awareness. This, however, was not within the remit of my work as a mentor, and so I will not consider it here.

Overall, during the teaching practices which are covered by this study, the students were obliged to complete 150 hours co-operating with schools at the three different levels, and this was organised in the following way:

primary -15 hours observation / 45 hours teaching 
Between didactics, the mentor and the pupils: Trainee reflections concerning...

lower secondary - 15 hours observation / 55 hours teaching upper secondary -5 hours observation / 15 hours teaching

Again, however, as with the semester timetable, there was some flexibility in the allocation of hours within the different levels - variations being negotiated between the trainees, myself and the director of the practices.

\section{The interviews as part of the mentor observation cycle}

\subsection{Overview}

The interviews with the student-teachers were carried out as part of the cycle of observations that were part of my duties as academic mentor. Normally, six students were observed once each semester. These observations entailed visiting the trainees in the schools in which they were fulfilling their practices, all the visits being pre-arranged and mutually agreed upon. Each observation was carried out during the course of one lesson - 45 minutes - during which time I sat in a designated area, usually at the back of the classroom, and completed the Observer Evaluation Record and took informal notes. These notes were fairly detailed in nature, giving a "blow-by-blow" account of what occurred - including the timing and descriptions of activities, as well as the actions of the student-teachers and learners during the course of the lesson. The notes also included my reactions, usually in the form of comments or descriptions and diagrams, including suggestions for alternative ways of working with the learners or exploiting materials.

\subsection{Time and place of the interviews}

The interviews took place as soon as possible after each observed lesson. This was usually two to seven days after the observed lesson had taken place. On rare occasions, the interviews were undertaken straight after the observed lesson, on the school premises, or up to two weeks later, at the university. These were exceptions, however, mostly because timetabling would not allow any other possibilities.

The benefit of allowing a period of time after the lesson, but not too long, was that the trainees had time to reflect upon the lesson they had taught and make notes about it, but not long enough to forget what had occurred. In interviews that occurred straight after the taught lesson, or where a greater time span had elapsed, it was noticeable that the students had less to say in the initial stages of the interview. In addition to this, when the interviews were 
carried out in the school, the quality of the recording was invariably poor, interference coming from surrounding activity.

\subsection{Interview procedure}

The interviews were carried out between myself and the student-teachers, and recorded using the Dictaphone application on my mobile telephone. There were four stages to each interview.

In the first stage, I invited the student-teachers to talk about the lesson they had taught, first of all concentrating on the positive aspects, and then moving on to those aspects that with hindsight, they would do differently. In this part, the students recounted their lessons with little comment from myself, only an occasional sound of confirmation or encouragement for them to continue. I did, however, interfere more directly if the student did not start with the positive aspects first of all, or they appeared to dry up. In the latter case, this meant suggesting a particular area to consider, or simply the question: "Is there anything else you'd like to say?"

In the second stage, the student-teachers were presented with an A4 sheet of paper upon which the following words/phrases were written: You; Children; Mentor; Methodology course. They were then asked to reconsider the lesson they had just commented upon with regard to what these people would say about it (with the methodology course, the trainees were asked to consider the reactions of the people running the course). As the first part of the interview had involved the students in commenting mostly from their own point of view, I usually asked them to move on to the other three people, although they could add more information from their own perspective if they wanted to. In this part of the interview, the trainees commented predominantly.

In the third stage of the interview, the roles were reversed. I made most of the commentary and the student-teachers either engaged in elucidating ideas, prompted by my remarks or questions, or listened to what I was saying making few remarks of their own. As I have mentioned above, this part of the interview was also based upon the notes made during the observation of the lesson.

For the fourth stage of the interview, the student-teachers were presented with the Observer Evaluation Record which I had completed during my observation of the lesson they had taught. In the majority of cases this acted as a summary of the discussions that had taken place, as the areas marked or comments made had either been mentioned by the students themselves, or were contained in the feedback I gave from the informal notes. 


\subsection{Length of interviews}

Each of the interviews lasted between just over twenty minutes or close on forty minutes. The differences in time were for a number of reasons. One, as mentioned above, was the time factor involved: whether or not the interview was carried out immediately or after a longer delay, or with a short delay of a few days, giving the student-teachers a chance to reflect upon and note down the thoughts they had about the lesson. In connection with this, the majority of short delay students were able to come up with more ideas and express themselves more clearly than those who either had feedback immediately or had a longer delay before feedback. Another reason was whether or not the student had anything to say, as some of them were more reticent than others. The length of the interviews overall also depended on what I had to say about the lessons. In addition, for some students I had quite extensive notes, or the feedback became something akin to a conversation, where the student and myself put forward ideas. On these occasions the third part of the interviews was noticeably longer than parts one and two.

All of the student-teachers involved in the study gave verbal consent to be recorded and for the resulting interviews to be used for research purposes. In the interview extracts shown in the following section, ST is student-teacher, while the number that follows is the number of the recorded interview. None of the extracts have been changed or corrected in terms of language, but appear as they were spoken by the students involved.

\section{Discussion - the interviews}

In stage two of the interviews, when the student-teachers were talking about significant others, personal attitudes and beliefs towards teaching and learning were apparent. However, the situation appears to be different to that which Kębłowska (2006) had hypothesised for an inquiry which covered a similar constituency, that "even if they [students] do learn new approaches [...] and principles of teaching, they do not consider them useful or relevant and tend to stick to their own ideas about language learning / teaching which are often solely based on their experiences as learners" (163). The student-teachers from my own inquiry showed themselves to be aware of and in the majority of cases trying to implement ideas they had received on their didactics courses, something which was borne out by the lessons I observed and also the way in which the students spoke about their experiences. And, although their discussions of significant others in relation to their practices contained a mixture of ideas, displaying what Bruner (1996: 44-65) has termed folk pedagogy, the 
versions the students were applying also included those offered by "'proper' pedagogical theorist[s]" (46), which was not only shown in their use of metalanguage to describe their experiences, but also their descriptions of attempts to implement particular concepts concerning the teaching of foreign languages.

From the examples I give below, for instance, this includes the students talking about pairwork and group work, or ideas relating to giving explanations and use of instructions, as well as the strategy of omitting exercises from a coursebook. It was also an awareness of affective factors as being important to learning, and therefore to ensure a lesson and the activities proposed engaged the learners. From a number of interviews not included here, it included the use of terminology related to lexis and grammar ${ }^{4}$, and an understanding that the learner might have a different way of looking at / doing things to the teacher ${ }^{5}$.

Overall, the interviews with the student-teachers concerning "significant others" provided different perspectives from which to view the lessons they were teaching. Ones which, as I have mentioned, made me less reliant upon the $O b$ server Evaluation Record, a form that I used for the purposes of assessment when observing the student-teachers' lessons, but which I felt to be too restrictive.

Indeed, one of the ways in which this worked was how the studentteachers talked about their relations with the "significant others". So that as I have described above, they used meta-language or signalled ideas connected with language teaching ("proper" pedagogical theory), even if the language they used hinted at rather than named an idea explicitly: an example from below might be the importance of affective factors couched in terms of the students having fun. In addition to this, during the interviews, issues appeared with regard to these "significant others" that had some bearing upon the involvement of the student-teachers carrying out their lessons, and which were consequently taken into account when assessing the lessons.

\subsection{Children}

In connection with the children, there were a number of responses that placed them at the centre of the activity the student-teachers were involved in. In these cases it might be said that the student-teachers were working with the children for the children:

\footnotetext{
${ }^{4}$ Interview ST7 where the student talked about the children beginning to understand working with adjectives, and more especially, comparatives and superlatives.

${ }^{5}$ Interview ST3, in which the student talked about trying to be open to how the learners themselves worked or thought, adjusting her involvement with them appropriately.
} 
ST16: I was pleased, erm, when I saw children who are involved in the lesson. And for me it was really, it was great. And the tasks which I prepared, $\mathrm{mmm}$, were I think, em, quite OK, and students wanted to work, with the stuff. [...] I was walking around the students' desks and trying to help them, if they had some problems with the task.

This child-centred view was also prevalent in a number of responses where the students mentioned the use of the coursebook. In such situations, it could be said that for the purposes of the observed lesson the students saw themselves as working with and for the children and not a coursebook which appeared to be the more usual practice in school:

ST9: OK, so, children told me that it was fun, cos I asked them afterwards. Err, they could learn something, but because of this relaxed atmosphere, I think they, err, kind of, err, didn't do it as, err, you know, as strict English lesson, cos they are always doing exercises with the book. And we were doing some pairwork, group work, you know, word search, so it was more fun for them than English lesson.

In terms of assessment, in cases where the children were placed at the centre of the teaching endeavour, I responded positively.

\subsection{Methodology course}

Domination of the coursebook over and above other forms of involvement was something that was problematic for student-teachers when they considered the methodology course. Here, a number of the student-teachers acknowledged the fact that the ideas and activities given on the course were useful to engage the children (which can also be seen from response ST16 given above) but that this usefulness was negated by a school practice that was coursebook and test orientated:

ST21: ...our methodology course here, is something different to school. For example, we, we, err, get some, err, kinds of writing, or reading activities. Or how to correct mistakes in, err, composition, or, err, short written form. And, err, I'm not using it during my teaching practice. Because, you know, I have a coursebook, and I have to do this, this, and this. And, err, I can't to create something new, because I know that they will have the test for, at the end of each chapter, and, erm, I have to do what they expect. But when I see that they, err, have problem with, erm, grammar, I, I can prepare something more. 
Interestingly enough, the lesson this student-teacher led did not use the coursebook, but a number of texts and a procedure that she herself had devised. This, however, appeared to be an exception related to the fact that the lesson was devoted to St Patrick's Day, a special occasion that meant she could be more creative in spite of the usual "school regime". Both the lesson as it was led, as well as the student's reflections upon her teaching practice were assessed positively.

\subsection{Mentor and you}

While the declarations in connection with the children and methodology course showed the complexity of the situation the student-teachers found themselves in, the comments relating to the mentor only added to this complexity. This created a picture of the student-teacher relationships with their mentors as one in which, after Witkowski (2007: 142-143), ambivalence was very much to the fore.

In one interview, for instance, the mentor was someone whose declarations were respected by the student-teacher, and significantly here, once again relate to the use of the coursebook:

ST3: [...] generally, I stick to the book, and I do the exercises, err, as they follow, so I do exercise number 1 , then exercise number 2 , exercise number 3 , and so on, and so on. Because, as my mentor mentioned, err, the book is done by the professional methodologist, and he or she, whoever done the book, knows exactly how the, the exercise should be, err, be introduced, in what, in which order.

In fact, this respect for the authoritative position of the mentor was also noticeable even though it seemed to inhibit this student-teacher's individual initiative:

ST3: I even thought about omitting one of the exercises, because I thought that it is, err, unuseful to, err, what I'm trying to introduce in the, err, the lesson, but, actually, my mentor, err she kind of, err, put me in the way of thinking that, they, they should be conducted in a, in a, orderly way, because if we omit one of the exercises, err, the parts of the next exercise, err, consists of the information given in the previous one, so, the-, they kind of follow each other, and they, they take from each other's, erm, ... So I didn't omit that exercise.

In such a case, the student-teacher/mentor relationship was taken into account when it came to talking about the observed lesson in stage three of the interview, as it explained the reason why and how the coursebook was used in this particular observed lesson. 
Between didactics, the mentor and the pupils: Trainee reflections concerning...

This does not mean that the students followed their mentors' suggestions on every single point without question. In some cases too, the differences of opinion that occurred appear to have been discussed with the mentor herself:

ST12: About my mentor, she told me that I use too little English during the lesson. But I argued with her because they [the pupils] simply do not understand me. Because, erm, it's not a long time, you know, the half of semester [...] to teach them. And, they, they have so, so many, I don't know how to s-, lackings, lacks...

Although in this particular case, it would seem that the relationship between the student-teacher and his mentor may have been "difficult", one in which he was not afraid to point out the inherent contradiction between what his mentor had said to him and what she herself did. Something which became apparent when the student-teacher was talking about himself (you) and his teaching practice in general:

ST12: Because at the beginning of my teaching practice I was trying, err, to, to speak in English, really, and they, at, at first, they were really [frustrated] that eventually someone is talking to them in English [...], because my mentor, erm, doesn't use so much English in class as well, that's why, why I was so surprised that she said to me that I should have used it more. And, I really think that they prefer that way of teaching [using Polish].

With regard to stage three of the interview with this student-teacher, the comments he made gave me a wider perspective from which to view his predominant use of Polish throughout the lesson. Although in doing so, I also brought a degree of circumspection, both to the justification and also its claims to being child-centred: After all, didn't the methodology course present techniques and activities that meant the classroom could be an English speaking environment? And, wasn't it more advantageous for the children to have contact with the English language through the teacher, even if they themselves may have had problems with understanding/using it?

If this particular student can be seen to be at odds with his mentor, at the other extreme there were also student-teachers who expected the mentor to have all the answers. In relation to the school mentor, this can be seen in the responses given by one student-teacher who expected more help from her mentor when it came to preparing the lesson I was to observe. Where the mentor "didn't really help me with this plan", and who when "I asked her if those tasks would be enough, that I should prepare more, or less, [...] said 'Well, I'm not sure what you should prepare, like this, and this, and...' "(ST4). In addition to this, there were also moments during the interviews where the 
student-teachers simply wanted me to tell them about their lessons. The example below came from the very beginning of one interview:

Martin: OK, do you want to tell me something about what you felt about what happened, what was going on?

ST9: I hope it was good. Ah, but, mmm, it might be a little bit disorganized, I think, and, $\mathrm{mmm}$, I have a problem with tasks, explanations and instructions. And I know it. Hum, there were no [...] So, it was good enough for me. But I would like you to tell me something about it.

This same student-teacher felt better able to talk about what had occurred in the lesson referring to the categories given in the Observer Evaluation Record, which she calls the mentor evaluation table:

ST9: OK, so, to make it easier I copied this, here, mentor's evaluation table. Uhh, OK, so about, err, preparation, aims of the lesson was clear, enough. Err, I think that the tasks were possible for them, but maybe too easy or too relaxed. Tasks were [...] and varied, so it was OK. And I think that, err, timing was good. About presentation, like I said, explanations are a little vague.

Overall, these two extracts show someone who wants to work within the given norms, either the ones I would lay down for her, or those presented as part of the practice documentation. Of course, from a student who needs to pass her teaching practice, of which the observation of her lesson and its assessment are a part, this is a very appropriate strategy. However, and as I mentioned above, it does seem to show the weakness of the Observer Evaluation Record as a tool by itself to look at and assess the experience of teaching. For, what is also noticeable here is the readiness of the student to look at her teaching as a number of boxes to be ticked, as well as a brief explanation to be given, rather than any deeper reflection ${ }^{6}$. And indeed, throughout this interview, I prompted the student to go further in her reflection.

\section{Conclusion}

The reasons for carrying out the research were to orientate myself within the different environments the trainees were working between, as well as promote

\footnotetext{
${ }^{6}$ Ironically, the brevity of her explanations could be said to be equal to the amount of space given on the Observer Evaluation Record for the mentor to write comments about the student's performance. In which case, the student appears to have understood only too well what the system of assessment was demanding of her.
} 
a dialogical and more reflective turn in connection with the assessment of the student-teachers' taught lessons. Additionally, I wanted to trial this procedure in terms of the data collection possibilities it offered. It being a procedure I hoped to use for research into teaching practices after 2012.

In looking at the effectiveness of the discussion procedure in terms of my orientation and promotion of reflection, the first two stages of the interviews allowed the student-teachers to give their version of events leading from the concrete situation of the lesson they had taught and which I had observed, to the more abstract considerations of how they believed the significant others would have reacted to the lesson. This was then followed by my discussion with the students in which I used the informal notes I had taken throughout my observation, as well as information I had gathered from the first two stages. The second stage, where the student-teachers reflected upon and talked about the lessons they had taught from the perspectives of significant others, also allowed for a fuller and broader consideration of what the students were involved in during their practices, which proved useful when I was discussing and then assessing the lessons they had taught in stages three and four of the interviews.

This opening out of the discussion to provide a broader context also gave useful information that could be used in a research project relating to student involvement in their practices as a whole. This would include using information from the interviews in conjunction with the reflections the student-teachers write as part of their teaching practice journals. Indeed, as can be seen in the discussion section above, the feedback discussions provided some interesting data concerning the use of the coursebook and L1/L2 use in the classroom, which used together with the information given by the students in their journals, would enable a rich picture of their involvement in the practices to be achieved. Additionally, and once more in relation to procedure, changes should be implemented. For this pilot study, the students were given the significant other types during the interview and not before. However, better results might be gained if the student-teachers are given these types to reflect upon at the end of the observed lesson, along with the instructions for thinking about the first stage of the interview (the positive aspects of the lesson and the things that might usefully be changed). This would allow them to prepare for the feedback/interview more fully, hopefully leading to even deeper reflection.

In terms of other changes to the procedure, some of the ways of labelling the significant others need to be reconsidered. In particular, children could be substituted with pupils or learners, because for the student-teachers carrying out their practices in gimnazjum or liceum, some of the people they 
were teaching were young adults rather than children ${ }^{7}$. Another change in this area would be to supply additional information concerning the term methodology course, where it might be stated that this includes the academic staff leading this subject at the university, but also myself as academic mentor. And finally, all the feedback-interviews should be carried out with no more than a four or five day interval between the time the students teach their lessons and discuss them, as those students that had such a break came most fully prepared in terms of their reflection for stage one of the interviews. This was not the case with those students who were involved in immediate feedback, while those students who came later appeared to have lost the impetus afforded by the occasion.

\section{BIBLIOGRAFIA}

Bruner, J. 1996. The Culture of Education. Cambridge: Harvard University Press.

Galewska-Kustra, M. 2009. „Studium przypadku w pedagogicznych badaniach nad twórczością. W poszukiwaniu praktycznych zastosowań metody" (w) Metody pedagogicznych badań nad twórczościq. Teoria i empiria (red. K.J. Szmidt). Łódź: Wydawnictwo Akademii Humanistyczno-Ekonomicznej w Łodzi: 225-275.

Heron, J. Reason, P. 1997. „A participatory inquiry paradigm”. Qualitative Inquiry 3(3): 274-294. Kębłowska, M. 2006. „Transferring ELT knowledge to the classroom - results of a study”. Glottodidactica 32: 159-171.

Mann, S. 2004. „Evaluation” (w) Adults learning languages: A CILT guide to good practice (red. H. Harnisch i P. Swanton). London: CILT:113-129.

Mann, S. i Walsh, S. 2015. „Reflective dimensions of CPD: supporting self-evaluation and peer-evaluation" (w) Teacher evaluation in second language education (red. H. Donaghue i A. Howard). London: Bloomsbury Academic: 17-34.

Mead, G.H. 1962. Mind, Self and Society: From the Standpoint of a Social Behaviourist. Chicago: The University of Chicago Press.

Mercado, L. A. i Mann, S. 2015. „Mentoring for teacher evaluation and development” (w) Teacher evaluation in second language education (red. H. Donaghue i A. Howard). London: Bloomsbury Academic: 35-54.

Schwandt, T.A. 1994. „Constructivist, interpretivist approaches to human inquiry” (w) Handbook of qualitative research (red. N.K. Denzin i Y. S. Lincoln). London: Sage Publications: 118-137.

\footnotetext{
${ }^{7}$ The term children was chosen because at the beginning of the project most of the student-teachers were carrying out their practices in primary schools. Only later did it become problematic, when I started visiting students in secondary schools. In the new practices, students at licencjat level only work with primary school children, whereas at the second level of their studies, magisterium, they can work at all three levels of schooling. A change then would make it possible to be applied across the whole range of compulsory schooling that the student-teachers' practices cover.
} 
Between didactics, the mentor and the pupils: Trainee reflections concerning...

Sullivan, H. S. 1953. The Interpersonal Theory of Psychiatry. New York: W.W. Norton \& Company, Inc.

Wallace, M.J. 2008. Action Research for Language Teachers. Cambridge: Cambridge University Press.

Witkowski, L. 2007. „Kwadratura aksjologicznego AIDS w pedagogice” (w) Edukacja wobec sporów o (po)nowoczesność (red. L. Witkowski). Warszawa: Instytut Badań Edukacyjnych: 141-152.

van Teijlingen, E. R. i Hundley, V. 2001. „The importance of pilot studies”. Social Research Update 35. http://sru.soc.surrey.ac.uk/SRU35.html DW 11.10.2014 